\title{
HAK-HAK KEWARISAN BANCI DALAM HUKUM ISLAM
}

\author{
Subehan Khalik
}

Fakultas Syariah dan Hukum Universitas Islam Negeri (UIN) Alauddin Makassar

\begin{abstract}
Islamic jurisprudence has placed a sissy as one of the legal phenomena and their existence has made the study of Islamic law in the field of inheritance to be more comprehensive. The sissy (khunșa) in Islamic inheritance law is only pinned to those who have multiple genitals. They are then identified based on the function of both genitals and defined their status based on the determination. Those who fail to pass through this process are then punished as an improper (muskilate) sissy. This group will get the smallest portion of inheritance from their portion while awaiting research on their final gender.
\end{abstract}

\section{Keywords:}

Inheritance, Sissy, Islamic Law

\begin{abstract}
Abstrak
Khasanah fikih Islam telah menempatkan banci sebagai salah satu fenomena hukum dan keberadaan mereka telah membuat kajian hukum Islam dalam lapangan kewarisan menjadi semakin komprehensif. Banci (khunșa) dalam hukum kewarisan Islam hanya disematkan kepada mereka yang memiliki kelamin ganda. Mereka kemudian diidentifikasi berdasarkan fungsi dari kedua alat kelamin tersebut dan ditetapkan status mereka berdasar dari penetapan itu. Mereka yang gagal melewati proses ini kemudian dihukumi sebagai banci (khunșa) musykil. Kelompok ini akan mendapatkan porsi kewarisan terkecil dari porsi mereka sambil menunggu penelitian terhadap jenis kelamin final mereka.
\end{abstract}

Kata Kunci:

Kewarisan, Banci, Hukum Islam

A. Latar Belakang Masalah

1 l $\begin{aligned} & \text { uhammadiyah sebagai ormas Islam terbesar di Indonesia telah } \\ & \text { menyatakan boikot mereka terhadap "Starbucks," karena mendukung } \\ & \text { pernikahan sejenis dan LGBT. Sebuah sikap yang sangat mengejutkan }\end{aligned}$ mengingat Muhammadiyah adalah gerakan ormas moderat dan menjadikan 
modernisasi sebagai salah satu kekuatan mereka dalam gerakan. ${ }^{1}$ Tengoklah amal usaha Muhammadiyah yang menggunakan modernisasi dalam pengelolaannya semisal rumahsakit, perguruan tinggi dan bahkan pengelolaan zakat lewat "lazismu".

Dalam releasnya, Ketua bidang ekonomi PP Muhammadiyah Anwar Abbas menegaskan sudah saatnya pemerintah Indonesia mempertimbangkan untuk mencabut ijin Starbucks di Indonesia. Karena Ideologi bisnis dan pandangan hidup yang Schultz kampanyekan jelas-jelas tidak sesuai dan sejalan dengan ideologi bangsa, yakni Pancasila. ${ }^{2}$ Sikap ini dipicu oleh pernyataan Howard Mark Schultz mendukung kesetaraan kaum Lesbian, Gay, Biseksual dan Transgender (LGBT). Ketika pertemuan dengan para pemilik saham Starbucks, Schultz secara tegas mempersilakan para pemegang saham yang tidak setuju dengan pernikahan sejenis angkat kaki dari Starbucks.

Sikap serupa dikemukakan oleh Dewan Perwakilan Rakyat (DPR) Wakil Ketua Komisi VIII DPR, Sodik Mujahid mengatakan, pernyataan CEO Strbucks, Howard Schultz sangat bertentangan dengan Pancasila. Sodik menyebut dukungan Schultz terkait gerakan LGBT (Lesbian, Gay, Biseksual, Transgender) sangat bertolak belakang dengan nilai-nilai yang dianut masyarakat Indoensia. "Semua pihak harus berani melawan upaya apapun yang akan merusak dan menghancurkan nilai-nilai Pancasila,". ${ }^{3}$

Pada sisi lain, LGBT memiliki status yang cukup membingunkan dalam kasus kewarisan Islam, sebab porsi pembagian kewarisan Islam berdasarkan jenis kelamin yang jelas. Mereka adalah pihak-pihak keturunan dari garis ayah (laki-laki) dan pihak ibu (perempuan). Keseluruhan ahli waris ini dikategorisasi secara kedekatan dengan zawil furūd, zawil arhām serta aśäbah. ${ }^{4}$ Semua ahli waris yang berhak dalam klasifikasi yang diurai hanya berasal dari dua jenis kelamin yang jelas yaitu laki-laki dan perempuan. Sementara pada sisi lain terdapat beberapa kelompok yang tidak memiliki status yang jelas pada jenis kelamin mereka, terutama pada kalangan yang dinamai sebagai khuntșa musykil dalam kewarisan Islam.

Uraian di atas kemudian melahirkan permasalahan pokok; Bagaimana status dan kewarisan Banci (khunșa) dalam hukum kewarisan Islam dengan sub masalah;

1. Bagaimana Hakikat dan Kedudukan Banci (khunșa) dalam Kewarisan Islam

2. Bagaimana hak-hak kewarisan Banci (khunșa) dalam hukum kewarisan Islam

\footnotetext{
${ }^{1}$ http://nasional.republika.co.id/berita/nasional/umum/17/06/29/osarle-pp-muhammadiyah-serukanboikot-starbucks-di-indonesia-ini-alasannya

${ }^{2}$ http://nasional.republika.co.id/berita/nasional/umum/17/06/29/osarle-pp-muhammadiyah-serukanboikot-starbucks-di-indonesia-ini-alasannya

${ }^{3}$ http://www.jawapos.com/read/2017/06/30/141112/dpr-dukung-muhammadiyah-boikot-starbucks

${ }^{4}$ Husnain Muhammad Mahluf, Al Mawariș Fi Syā' 'at al Islāmiyyah, (Kairo: Maṭbah al Madāni, 1976), h.33; Fathurrahman, Hukum Waris, (Bandung: Al Ma'arif, 1975), h. 150
} 


\section{B. Banci dalam Hukum Kewarisan Islam}

Secara etimologi, khunșa berasal dari kata khanașa yang berarti jenis kelamin yang terpecah. Maksud dari terpecah di sini yaitu memiliki alat kelamin lebih dari dua. ${ }^{5}$ Dinamai banci karena sikap kemayu seorang laki-laki yang menyerupai perempuan, cara berbicara dan bertutur mereka selembut perempuan. ${ }^{6}$ Dalam Kamus Besar Bahasa Indonesia, banci disebut sebagai manusia yang bersifat laki-laki dan perempuan (tidak laki-laki dan tidak perempuan), serta laki-laki yang bertingkahlaku menyerupai perempuan atau sebaliknya, wadam, waria. ${ }^{7}$ Dalam kitab fikih, banci didefenisikan sebagai khunșa (orang yang tidak jelas jenis kelaminnya) dan berbeda dengan banci. Penjelasan itu meliputi orang yang tidak jelas alat kelaminnya karena memiliki alat kelamin laki-laki dan perempuan secara bersamaan, atau tidak memiliki jenis kelamin samasekali. ${ }^{8}$

Banci dalam hukum kewarisan Islam identik dengan khunșa, namun konsep dan konotasi yang berlaku di masyarakat saat ini jauh berbeda. Banci identik dengan laki-laki yang berperilaku seperti perempuan sebagai akibat dari konstruksi sosial diri pelaku. ${ }^{9}$ Banci merupakan sikap yang lahir dari persepsi seorang pria jika dirinya terjebak dalam tubuh laki-laki. Mereka kemudian bertingkahlaku dan mengidentikkan diri sebagai wanita. ${ }^{10}$ Dalam beberapa bahasan, banci memiliki kecenderungan seksual terhadap sesama lelaki dan cenderung tidak memiliki ketertarikan lagi terhadap perempuan, berbeda dengan gay. Meski memiliki kasus seksual yang serupa namun gay lebih kompleks dibanding banci. Gay dalam kondisi tertentu memiliki hasrat seksual kepada lak-laki dan pada banyak secara bersamaan juga memiliki hasrat seksual kepada lawan jenis mereka.

Konteks banci rupanya telah ada pada masa Rasulullah saw. Dimana suatu ketika Rasulullah saw. memerintahkan untuk menjauhkan seorang banci di tengahtengah wanita muslimah. Selengkapnya hadis tersebut;
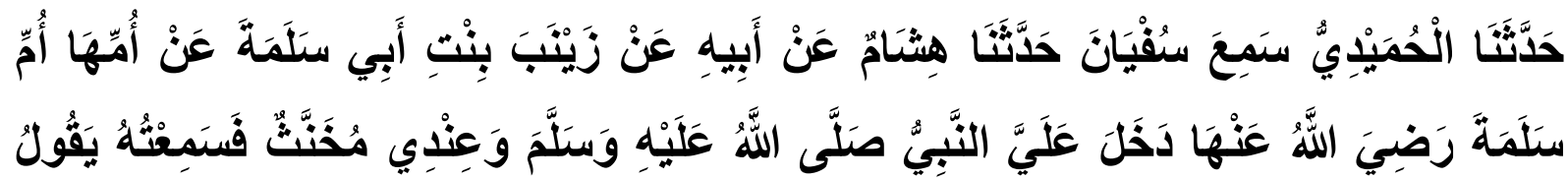

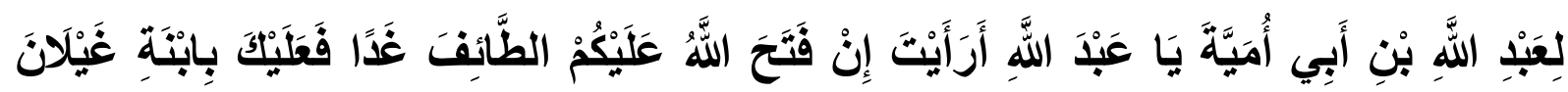

${ }^{5}$ Lihat Abū al-Husain Aḥmad ibn Fāris ibn Zakariya, Mu’jam Maqāyis al-Lughah, Juz II (Ttp: Dār alFikr, 1979 M/1319 H.), h. 1243.

${ }^{6}$ Lihat Muhammad 'Ali al-S̄ābūni, Al-Mawaṇ̃s Fi al-Syañ̄at al-Islāmiyyah Fi Daw'i al-Kitāb wa alSunnah (Beyrūt: Dār al-Kutub al-'Ilmiyyah, t.th), h. 1-8.

7 Departemen Pendidikan dan Kebudayaan, Kamus Besar Bahasa Indonesia (Jakarta: Balai Pustaka, 1988), h. 74

${ }^{8}$ Wahbah al-Zahailīy, al-Fiqh al-Islām wa Adillatuhu (Dār al-Fikr: Mesir, t.th.), h. 11.

${ }^{9}$ Lihat paparan teori "Konstruksi Sosial” menurut Peter L Berger dan Thomas Luckmann, The Social Construction of Reality A Treatise in the Sociology of Knowledge, (New York: 1966). Buku ini telah diterjemahkan ke dalam bahasa Indonesia dengan judul Tafsir Sosial atas Kenyataan, (Jakarta: LP3S, 1990), h. 23

${ }^{10}$ Koeswinarno, Hidup Sebagai Waria (Jogjakarta: KliS; 2004), h. 1 


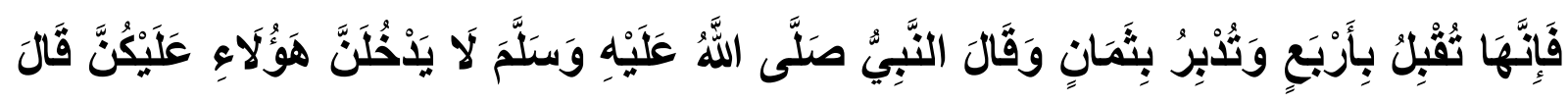

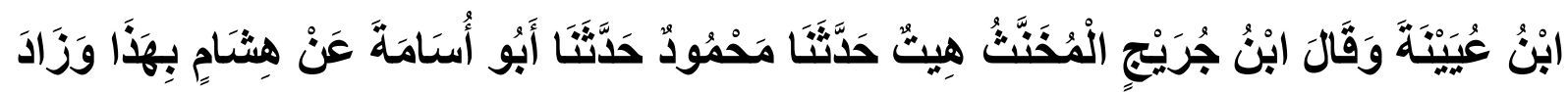

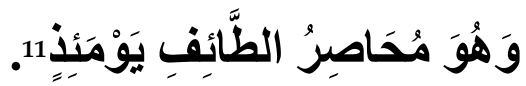

Terjemahnya:

Telah menceritakan kepada kami Al Humaidi ia mendengar Sufyan Telah menceritakan kepada kami Hisyām dari ayahnya dari Zaenab binti Abū Salamah dari Ibunya, Ummu Salamah Radiallāhu 'anha, Nabi Śallallahu 'alaihi wasallam menemuiku yang ketika itu disisiku ada seorang waria dan kudengar ia mengatakan kepada Abdullah bin Abu Umayyah; Wahai Abdullah, bagaimana pendapatmu jika Allah menalukkan Taif untukmu, hendaklah engkau menikahi anak perempuan Ghailan, sebab ia (perempuan) yang menghadap dengan empat cabang dan berbalik dengan delapan cabang. Maka Nabi shallallahu 'alaihi wasallam langsung berkomentar: "Jangan biarkan laki-laki waria (banci) itu menemui kalian. Kata Ibn Uyainah, Ibn Juraij mengatakan makna 'mukhannaș' adalah banci, Telah menceritakan kepada kami Maḥmūd Telah menceritakan kepada kami Abū Usāmah dari Hisyām dengan hadist ini dan beliau tambahkan redaksi; "Ketika itu beliau sedang mengepung kota Taif". ${ }^{12}$

Hadis di atas sangat masyhur dan diriwayatkan hampir di seluruh kitab Sembilan kecuali al-Nasai, Ibnu Majah dan sunan al-Darimiy. ${ }^{13}$ Pada kejadian ini Rasulullah saw. telah mengerti secara mendalam bahwa hasrat seksual banci kemungkinan masih ada mengingat jenis kelamin mereka berasal dari lelaki. Demikian pula sebaliknya terhadap kalangan lesbian. Ketidaklaziman dalam pergaulan membuat Rasul mengerti betul kesan yang akan timbul dari interaksi kaum muslimah denga banci. Azas kehati-hatian sangat terlihat pada alasan beliau untuk mengusir para banci jika bertandang ke rumah para sahabat dan kaum muslimah. Sikap tegas Rasulullah juga diriwayatkan dalam hadis berikut yang dikutip dari kitab sahih Muslim;

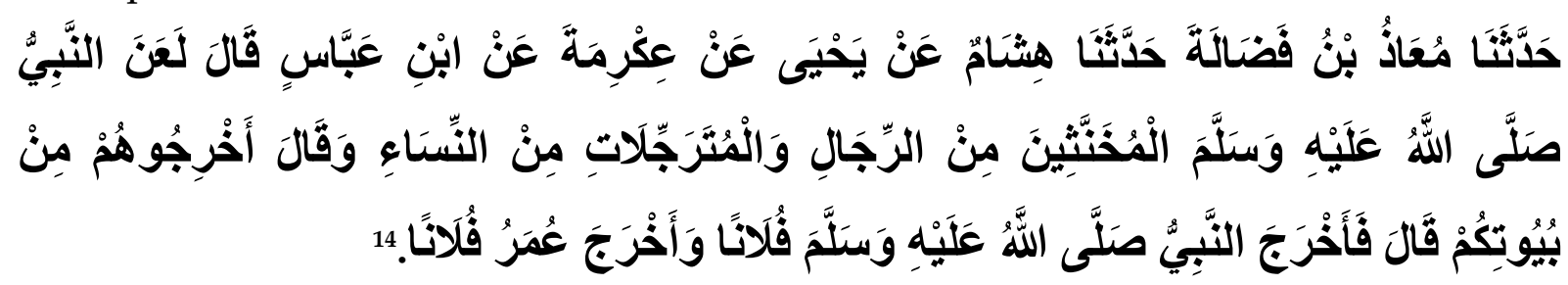

Terjemahnya:

"Ib Telah menceritakan kepada kami $M u^{\prime} \bar{a} z$ bin Faḍalah telah menceritakan kepada kami Hisyām dari Yahya dari Ikrimah dari Ibnu Abbas dia berkata; Nabi shallallahu 'alaihi wasallam melaknat para laki-laki yang menyerupai wanita dan para wanita yang menyerupai

\footnotetext{
${ }^{11}$ Muḥammad bin Ismā'il al-Bukhāriy, Śậhḥ al-Bukhāriy, Juz VII (Kairo: Dār Al-Sya‘biy, t.th.), h. 106.

12 Terjemahan Penulis

${ }^{13}$ Lihat, Lidwa Pusaka i-Software - Kitab 9 Imam Hadist

${ }^{14}$ Muḥammad bin Ismā‘il al-Bukhāriy, Śạ̄ịh al-Bukhāriy, Juz VII, h. 125
} 
laki-laki, sabdanya: "Keluarkanlah mereka dari rumah kalian."Ibnu 'Abbās melanjutkan; 'Maka Nabi șallallāhu 'alaihi wasallam pernah mengeluarkan seorang fulan begitu juga dengan Umar.'15

Dua hadis yang dikemukakan terdahulu sepintas mengandung makna tindakan pengucilan Rasulullah saw. dan 'Umar dengan mengusir si banci dari rumah mereka. Sebuah tindakan yang akan melahirkan antipati dari pencinta atau pelaku LGBT, namun di sisi hukum tindakan ini adalah sebuah penjelasan rinci jika banci masih dihukum oleh keduanya berdasarkan jenis kelamin asal mereka yakni laki-laki. Rasulullah saw. pada kondisi mengusir banci tersebut mengisyaratkan agar mereka tidak bergaul secara vulgar dengan wanita muslimah sebab mereka sebenarnya adalah lak-laki sejati.

Khunșa dalam kewarisan Islam membicarakan objek dan tekanan bahasannya pada alat kelamin yang dimiliki oleh ahli waris. Dalam bahasan ini, kepemilikan dua alat kelamin atau ketiadannya samasekali membuat kebingungan dalam menghukum apakah yang bersangkutan itu berjeniskelamin laki-laki atau perempuan. Pola ini melahirkan kebingungan dalam menentukan bagian ahli waris tersebut sebab ayat mawaris secara tegas mencantumkan bagian-bagian tersebut atas dasar jenis kelamin para ahli waris. Lihatlah misalnya dengan apa yang dicantumkan dalam QS. (4): 7 sebagai berikut:

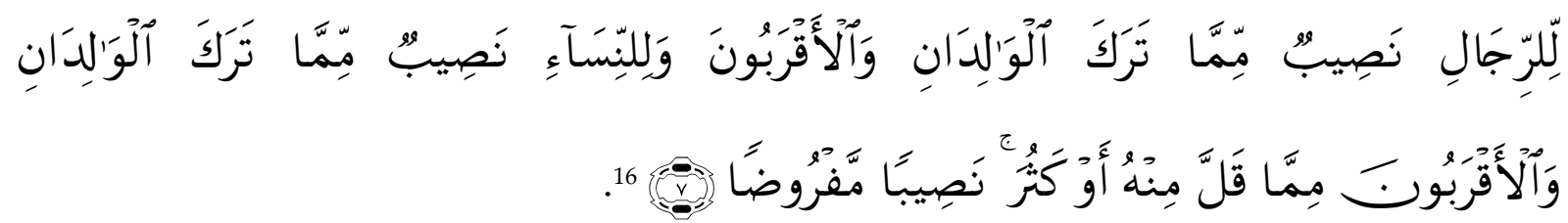

Terjemahnya:

Bagi orang laki-laki ada hak bagian dari harta peninggalan ibu-bapa dan kerabatnya, dan bagi orang wanita ada hak bagian (pula) dari harta peninggalan ibu-bapa dan kerabatnya, baik sedikit atau banyak menurut bahagian yang telah ditetapkan.

Ayat ini menjelaskan secara rinci jenis kelamin yang akan mendapatkan bagian dari pusaka yang ditinggalkan oleh orang tua mereka serta karib kerabatnya. Jelas mengisyaratkan bahwa hanya dua jenis kelamin yang akan mendapatkan bagian secara jelas. Kehadiran seorang khunșa diperhadapkan dengan ayat di atas akan menimbulkan ambiguitas dalam penentuan jenis kelamin si pewaris. Mengantisipasi kebingungan tersebut, fuqaha telah membuat solusi dari kebingungan ini. Solusi yang dimaksud adalah upaya untuk memperjelas status jenis kelamin ganda dengan menguji fungsi dari kedua kelamin tersebut.

Ilmu kedokteran menamai khunșa dengan hermafroditisme yang secara medis terbagi menjadi;

\footnotetext{
15 Terjemahan penulis

${ }^{16}$ Kementerian Agama RI., Alquran dan Terjemahnya (Toha Putera: Semarang; 2016), h. 118
} 
1. Individu yang memiliki alat kelamin lateral yaitu pada satu sisi memiliki testis dan pada sisi lainnya memiliki ovarium

2. Individu yang memiliki alat kelamin Unilateral yaitu alat kelamin mirip laki-laki dan perempuan pada satu sisi dan sisi lainnya memiliki ovarium atau testis pada sisi lainnya

3. Individu yang memiliki alat kelamin Bilateral yaitu alat kelamin mirip laki-laki dan perempuan pada satu sisi dan pada sisi lainnya alat kelamin yang mirip alat kelamin laki-laki dan perempuan. ${ }^{17}$

Fuqaha menyikapi khunșa dengan mengadakan pendeteksian secara sederhana terhadap alat kelamin yaitu dengan memperhatikan pada bagian mana air seni keluar jika khunșa buang air kecil. Jika air seninya keluar pada organ kelamin lakilaki maka ia dikategori sebagai seorang laki-laki atau sebaliknya. Akan halnya jika kemudian ternyata air seni tersebut keluar pada kedua alat kelamin ini, maka khunșa tadi dikategorisasi sebagai khunșa musykil. yaitu khunșa dengan jenis kelamin yang tidak jelas. ${ }^{18}$

Dalam kajian fikih, khunșa dibagi dalam dua garis besar yaitu khunșa musykil yaitu khunșa dengan jenis kelamin yang tidak jelas (adakalanya khunșa ini tidak memiliki alat kelamin dan kadang pula memiliki dua alat kelamin berbeda). Sementara itu terdapat pula khunșa dengan jenis kelamin yang jelas, jika ternyata di antara dua jenis kelamin tersebut berfungsi normal dan satunya lagi tidak berfungsi. Terhadap khunșa musykil biasanya fukaha menunda bagian warisnya sampai ahli waris tersebut dewasa guna mengetahui jeis kelamin sejatinya. ${ }^{19}$ Pemikiran fukaha untuk menunda bagian ahli waris khunșa sejalan dengan aspek kekinian dimana gugatan penggantian alat kelamin melalui jalur hokum sudah biasa terjadi.

Kasus sidang ganti kelamin setidaknya pernah terjadi di Pengadilan Negeri Purwokerto. Dalam kasus ini seorang yang bernama Solihatunnisa warga kelurahan Karangklesem, Kecamatan Purwokerto Selatan. Dalam siding ini terungkap bahwa Solihatunnisa terlahir dengan jenis kelamin perempuan, namun sepuluh hari pasca kelahirannya Solihatunnisa tampak memiliki alat kelamin laki-laki. Perkembangan selanjutnya, Solihatunnisa hidup dengan memiliki dua jenis alat kelamin yaitu lakilaki dan perempuan hingga ia dewasa. Gelagat inilah yang kemudian mengundang keingintahuan orang tuanya untuk mengetahui persis jenis kelamin anaknya dengan membawanya ke Rumah Sakit Sardjito Yogyakarta dan hasilnya sangat mencengang kan. Ternyata Solihatunnisa yang selama ini mereka kira sebagai perempuan

17 Bagian Obsteri dan Ginekologi Fakultas Kedokteran Universitas Pajajaran Bandung, Ginekologi (Bandung: Elstar, 1981), h. 51; , Suryo, Genetika Manusia (Yogyakarta: Gajah Mada University Press, 1988), h.6

${ }^{18}$ Lihat Badran Abu al-'Aynain Badran, Al-Mawāriș wa Al-Waśiyyat wa al-Hibat Fi al-Syañ 'at alIslāmiyyat wa al-Qanūn, (T.tp., t.th.), h. 104; Sayyid al-Sābiq, Fiqh al-Sunnah (Beirut: Dār al-Kitab, 1391 H./1981 M), h. 657-665; Muslih Maruzi, Pokok-Pokok Ilmu Waris, Cet. I (Semarang: Mujahidin, 1980), h. 88.

${ }^{19}$ Fathur Rahman, Ilmu Waris, Cet. 10 (Bandung: al-Ma'arif, 1975), h. 484. Wahbah al-Zuhailīy, al-Fiqh al-Islam, h. 13. 
berdasarkan hasil pemeriksaan medis secara sah dan terbukti memiliki jenis kromosom " $\mathrm{XY}$ " dan secara klinik tidak memiliki Rahim. ${ }^{20}$

Proses kematangan alat seksual yang menjadi pertimbangan fukaha untuk menentukan bagian waris khunșa merupakan jalan keluar yang baik mengantisipasi kekacauan jenis kelamin dari seorang khunșa. Mengambil pelajaran dari kasus di atas, seorang hakim dalam kasus khunșa sangat diajurkan untuk mempertimbangkan pendapat ahli kedokteran terhadap penentuan jenis kelamin khunșa.

\section{Hak-hak Kewarisan Khunșa}

Seorang banci (khunșa) dalam kewarisan Islam tetap akan mendapat hak-hak kewarisan mereka. Namun proses ini harus meliputi beberapa langkah kongkrit yang mengarah pada kejelasan alat kelaminnya. Kejelasan alat kelamin yang dimiliki merupakan syarat standar dalam penentuan saham mereka sebab dengan jenis kelaminlah saham-saham dalam kewarisan Islam akan dibagikan. Faktor jenis kelamin sangat jelas pengaruhnya dalam pembagian kewarisan seorang khunșa sebab jenis kelamin memegang peranan besar dalam penentuan besar kecilnya saham mereka. Sebagai gambaran dapat diperhatikan pada bagian-bagian ahli waris yang tertera dalam furūdul muqaddarah dalam QS. Al-Nisa (4): 12 sebagai berikut:

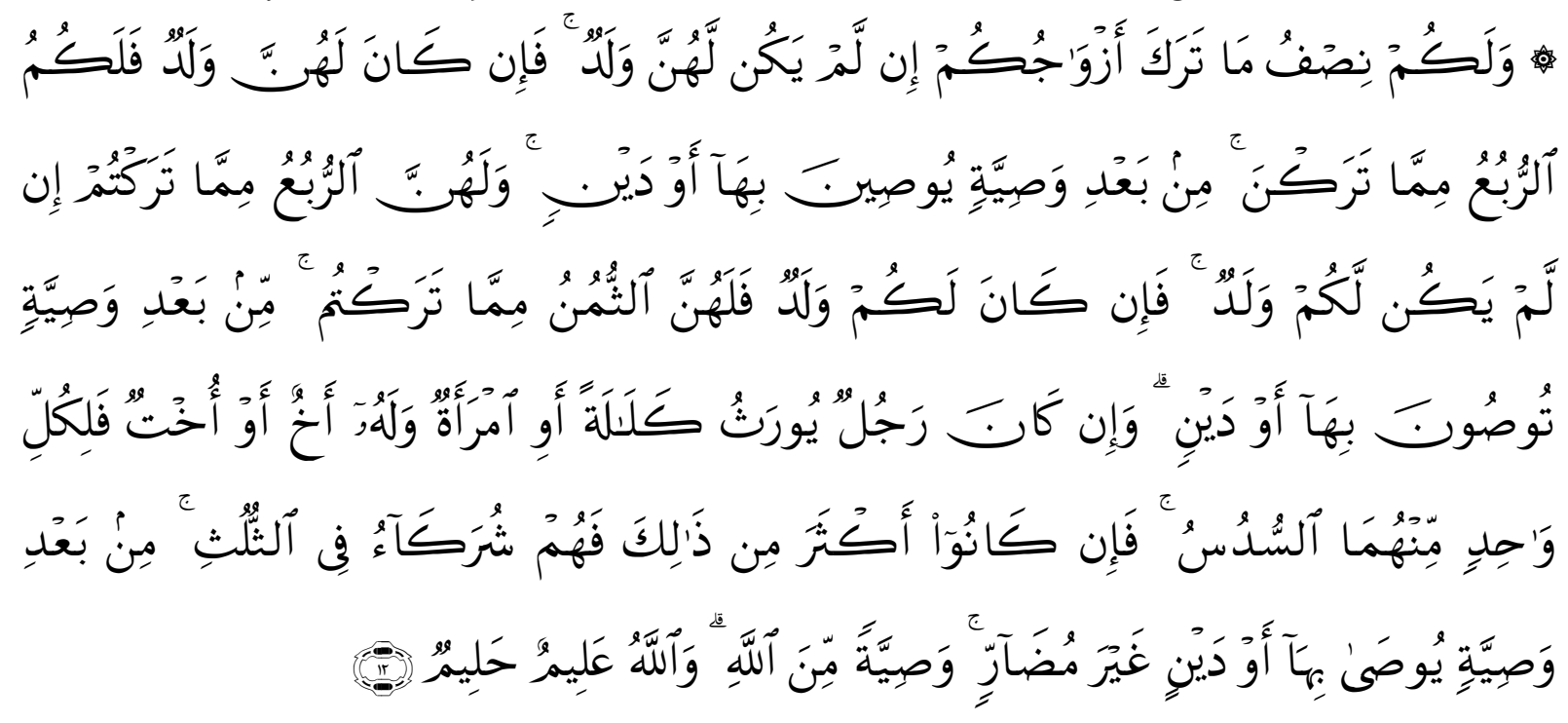

Terjemahnya:

12. dan bagimu (suami-suami) seperdua dari harta yang ditinggalkan oleh isteri-isterimu, jika mereka tidak mempunyai anak. jika isteri-isterimu itu mempunyai anak, Maka kamu mendapat seperempat dari harta yang ditinggalkannya sesudah dipenuhi wasiat yang mereka buat atau (dan) seduah dibayar hutangnya. Para isteri memperoleh seperempat harta yang kamu tinggalkan jika kamu tidak mempunyai anak. jika kamu mempunyai anak, Maka Para isteri memperoleh seperdelapan dari harta yang kamu tinggalkan sesudah dipenuhi wasiat yang kamu buat atau (dan) sesudah dibayar hutang-hutangmu. jika seseorang mati, baik laki-

\footnotetext{
${ }^{20} \mathrm{http}: / / w w w . r e p u b l i k a . c o . i d /$ berita/senggang/unik/08/12/24/22219-ganti-kelamin-disidangkan-pnpurwokerto
} 
laki maupun perempuan yang tidak meninggalkan ayah dan tidak meninggalkan anak, tetapi mempunyai seorang saudara laki-laki (seibu saja) atau seorang saudara perempuan (seibu saja), Maka bagi masing-masing dari kedua jenis saudara itu seperenam harta. tetapi jika saudara-saudara seibu itu lebih dari seorang, Maka mereka bersekutu dalam yang sepertiga itu, sesudah dipenuhi wasiat yang dibuat olehnya atau sesudah dibayar hutangnya dengan tidak memberi mudharat (kepada ahli waris) [274]. (Allah menetapkan yang demikian itu sebagai) syari'at yang benar-benar dari Allah, dan Allah Maha mengetahui lagi Maha Penyantun. ${ }^{21}$

Secara tegas bagian-bagian ahli waris diurai dalam ayat ini berdasarkan kedekatan dengan pewaris dan mempertimbangkan jenis kelamin mereka. Seorang suami akan berbeda bagiannya dengan isteri yang ditinggal oleh pewaris. Ayat ini juga secara spesifik menguraikan sebab kewarisan dari dua unsur; pertama unsur perkawinan dan unsur kekerabatan. Kedua unsur ini dikaitkan pula dengan jenis kelamin yang dimiliki oleh ahli waris. Sekali lagi pencantuman sebab-sebab kewarisan pada ayat ini tetap konsisten pada jenis kelamin laki-laki dan perempuan dan tidak memberi peluang sedikitpun kepada banci (khunșa) untuk memiliki harta warisan.

Kebuntuan terhadap porsi warisan banci (khunșa) dijelaskan oleh fukaha dengan memberi mereka porsi tertentu kepada mereka secara menggantung. Maksudnya, porsi kewarisan terhadap banci (khunșa) diberikan kepada mereka dalam bentuk separuh, menunggu sampai kemudian ada kejelasan terhadap status jenis kelamin yang bersangkutan. Secara ringkas pendapat fukaha terhadap porsi kewarisan banci (khunșa) dapat dilihat sebagai berikut:

1. Menurut Imam Abu Hanifah, Abu Yusuf, banci (khunșa) musykil mendapat bahagian terkecil dari dua perkiraan antara bagian kewarisan laki-laki dan perempuan, dari sisa porsi yang diberikan kepada ahli waris lain.

2. Golongan Syafi'iyah, Abu Daud, memberikan porsi kepada banci (khunșa) berdasarkan perhitungan terkecil, sisa porsi mereka ditangguhkan sambil menunggu dan mengadakan penelitian jenis banci (khunșa) guna diselesaikan secara musyawarah mufakat.

3. Menurut golongan Malikiyah, Syi'ah, memberikan banci (khunșa) separuh dari dua perkiraan laki-laki dan perempuan. ${ }^{22}$

Pandapat fukaha telah mengatur bagian terhadap banci (khunșa) dengan memberi mereka separuh bagian laki-laki dan perempuan, memberi kejelasan hukum sementara sambil menunggu penelitian terhadap jenis kelamin pasti mereka.

Fukaha telah pula menyinggung peluang timbulnya banci (khunșa) musykil dalam garis keturunan meliputi:

${ }^{21}$ Kementerian Agama RI., Alquran dan Terjemahnya, h. 117

${ }^{22}$ Lihat Muslih Maruzi, Pokok-Pokok Ilmu Waris, h. 86; Bandingkan dengan Badran Abū al-'Aynain Badran, Al-Mawān̄is h. 103; Sayyid al-Sābiq, Fiqh al-Sunnah h. 655-666 
1. Garis keturunan anak ke bawah; meliputi anak, cucu dan seterusnya

2. Garis kesaudaraan meliputi; saudara, ponaka (anak dari saudara)

3. Garis kepamanan meliputi; paman dan akan paman (sepupu)

4. Garis perbudakan. ${ }^{23}$

Berikut tatacara penyelesaian kasus banci (khunșa) musykil dalam urusan kewarisan berdasarkan simpulan pendapat fukaha:

1. Upaya pertama yang harus dilakukan adalah dengan cara mencari tahu kejelasan jenis kelamin dari banci (khunșa) musykil tersebut dari proses berkemih mereka. Jika ternyata banci (khunșa) musykil berkemih dengan menggunakan organ kelamin laki-laki maka ia dihukumi sebagai laki-laki dan begitupula sebaliknya.

2. Meneliti ciri kedewasaannya (tentu ini membutuhkan waktu) yang mungkin akan mengidentifikasi ciri kedewasaan seorang laki-laki ataupun perempuan. Ciri-ciri ini dapat berupa tumbuhnya kumis dan jenggot bagi laki-laki dan buah dada yang membesar bagi perempuan.

3. Jika dua proses di atas mengalami kebuntuan, maka pendapat fukaha tentang penentuan bagian lebih kecil dari ahli waris laki-laki dan perempuan segera diimplementasikan seraya menunggu kejelasan jenis kelamin mereka. ${ }^{24}$

Pertanyaan yang muncul kemudian adalah; bagaimana status laki-laki tulen yang menyerupai perempuan dalam tindak tanduk dan sikap mereka atau sebaliknya. Jawaban yang terlintas adalah; bagi mereka (banci atau lesbian) mereka tetap dihukum berdasarkan jenis kelamin inti mereka. Sebab mereka tidak dalam memberi kebingungan terhadap status jenis kelamin mereka, walaupun mereka bertindak dan berprilaku berbeda dengan jenis kelamin mereka. Bisa jadi mereka inilah yang kemudian dilaknat oleh Allah dalam beberapa riwayat yang berasal dari Ibnu Abbas dan pada kesempatan ini tidak dikutip karena kejelasan sumber.

\section{Kesimpulan}

Khasanah fikih Islam telah menempatkan banci sebagai salah satu fenomena hukum dan keberadaan mereka telah membuat kajian hukum Islam dalam lapangan kewarisan menjadi semakin konfrehensip. Banci (khunșa) dalam hukum kewarisan Islam hanya disematkan kepada mereka yang memiliki kelamin ganda. Mereka kemudian diidentifikasi berdasarkan fungsi dari kedua alat kelamin tersebut dan ditetapkan status mereka berdasar dari penetapan itu. Mereka yang gagal melewati proses ini kemudian dihukumi sebagai banci (khunșa) musykil. Kelompok ini akan mendapatkan porsi kewarisan terkecil dari porsi mereka sambil menunggu penelitian terhadap jenis kelamin final mereka. Proses dimaksud meliputi; ciri

${ }^{23}$ Muhibuddin Abdul Wahid, Hukum Kewarisan Islam Sebagai Pembaruan Hukum Positif di Indonesaia (Jakarta: Sinar Grafika, 2009), h. 136.

${ }^{24}$ Suhrawardi K. Lubis Komis Simanjuntak, Hukum Waris Islam (Jakarta: Sinar Grafika, 2008), h. 7172. 
kedewasaan dan penetapan ahli lewat penelitian ilmu kedokteran dalam deteksi jenis kelamin mereka.

Banci (khunșa) dalam fikih Islam hanya dikenal bagi mereka yang memilik alat kelamin ganda atau tidak memiliki alat kelamin semasekali. Status ini tidak disematkan bagi laki-laki yang bertingkahlaku seperti perempuan atau sebaliknya, bahkan di beberapa hadis Rasulullah saw. Menyuruh sahabat untuk mengusir mereka dari rumah untuk menghindari mereka bergaul dengan isteri-isteri sahabat.

Konotasi banci dalam kewarisan Islam berbeda telak dengan konotasi sosial saat ini, dimana banci adalah mereka (laki-laki) yang merasa dirinya adalah perempuan yang terpenjara dalam tubuh laki-laki. Oleh Rasulullah saw. Banci inilah yang kemudian diperintahkan untuk diusir dan tidak diberi peluang untuk bergaul dengan kaum muslimah sebab pada hakekatnya mereka itu adalah laki-laki tulen. Untuk kasus ini, mereka para banci tetap mendapatkan hak kewarisan mereka sesuai dengan porsi laki-laki yang diatur dalam furūd al-muqaddarah.

\section{Daftar Pustaka}

'Ali al-Sābūni, Muhammad, Al-Mawarīṣ Fì al-Syarī'at al-Islāmiyyah Fī Daw'i al-Kitāb wa al-Sunnah (Beyrūt: Dār al-Kutub al-'Ilmiyyah, t.th)

Aḥmad ibn Fāris ibn Zakariya, Abū al-Ḥusain, Mu'jam Maqāyis al-Lughah, Juz II (Ttp: Dār al-Fikr, 1979 M/1319 H.)

al-Sābiq, Sayyid, Fiqh al-Sunnah (Beirut: Dār al-Kitab, 1391 H./1981 M)

al-Zahailīy, Wahbah, al-Figh al-Islām wa Adillatuhu (Dār al-Fikr: Mesir, t.th.)

Badran Abu al-'Aynain Badran, Al-Mawāriș wa Al-Wasizyyat wa al-Hibat Fī al-Syarī‘at al-Islāmiyyat wa al-Qanūn, (T.tp., t.th.), h. 104;

Bagian Obsteri dan Ginekologi Fakultas Kedokteran Universitas Pajajaran Bandung, Ginekologi (Bandung: Elstar, 1981)

Departemen Pendidikan dan Kebudayaan, Kamus Besar Bahasa Indonesia (Jakarta: Balai Pustaka, 1988)

Fathurrahman, Hukum Waris, (Bandung: Al Ma'arif, 1975)

Kementerian Agama RI., Alquran dan Terjemahnya (Toha Putera: Semarang; 2016)

Koeswinarno „Hidup Sebagai Waria (Jogjakarta: KliS; 2004)

Mahluf, Husnain Muhammad, Al Mawāriș Fī al-Syarī'at al Islāmiyyah, (Kairo: Mathbah al Madani, 1976)

al-Bukhāriy, Muḥammad bin Ismā’il, Śahịḥ al-Bukhāriy, Juz VII (Kairo: Dār AlSya'biy, t.th.)

Muhibuddin, Abdul Wahid. Hukum Kewarisan Islam Sebagai Pembaruan Hukum Positif di Indonesaia (Jakarta: Sinar Grafika, 2009) 
Muslih, Maruzi, Pokok-Pokok Ilmu Waris, Cet. I (Semarang: Mujahidin, 1980)

Peter L Berger dan Thomas Luckmann, Tafsir Sosial atas Kenyataan, (Jakarta: LP3S, 1990)

Rahman, Fathur, Ilmu Waris, Cet. 10 (Bandung: al-Ma'arif, 1975)

Simanjuntak, Suhrawardi K. Lubis Komis, Hukum Waris Islam (Jakarta: Sinar Grafika, 2008)

Suryo, Genetika Manusia (Yogyakarta: Gajah Mada University Press, 1988)

Sumber-sumber lain:

http://www.republika.co.id/berita/senggang/unik/08/12/24/22219-ganti-kelamindisidangkan-pn-purwokerto

http://nasional.republika.co.id/berita/nasional/umum/17/06/29/osarle-ppmuhammadiyah-serukan- boikot-starbucks-di-indonesia-ini-alasannya

http://www.jawapos.com/read/2017/06/30/141112/dpr-dukung-muhammadiyahboikot-starbucks 